\title{
Distribution of selected invasive plant species in the Romensko-Poltavsky Geobotanical District (Ukraine)
}

\author{
Tetyana S. Dvirna
}

M. G. Kholodny Institute of Botany, National Academy of Sciences of Ukraine, Tereschenkivska 2, 01601 Kiev, Ukraine, e-mail: dvirna $t @$ ukr.net

\begin{abstract}
The paper presents the distribution of 10 selected invasive plant species in the Romensko-Poltavsky Geobotanical District (Ukraine). The studied taxa comprised 8 invasive and 2 potentially invasive species. All species were characterized in phytogeographical, biological and ecological terms. Their distribution was shown on grid maps.
\end{abstract}

Key words: invasive species, maps of distribution, Romensko-Poltavsky Geobotanical District, Ukraine

\section{Introduction}

One of the most actual threats to biodiversity is biological invasion (Baldacchino \& Pizzuto 1996; Davis 2003; Sax \& Gaines 2003; Protopopova et. al. $2002,2003)$. Invasive species can cause serious and irreversible processes in natural environment (disruption of normal ecosystem functioning, impoverishment of species composition, loss of native species, changes in natural communities) and in the economy; according to expert estimates, damage from invasive alien species worldwide totals billions of dollars every year. Proof of the importance of this problem was the discussion at the UN conference, dedicated to the conservation of biodiversity: problems of sustainable development - Rio de Janeiro, Brazil (1992), as well as conferences and special forums devoted to plant invasions: "Biological pollution: the control and impact of invasive exotic species" - Indiana (1993), "Plant Invasions. General aspects and special problems" - Amsterdam (1995), "International conference on the ecology of invasive alien plants" Berlin (1997), "Alien and synanthropic flora of Russia and neighbour countries: status and prospects" - Izhevsk (2006) and "Invasion biology: current state and prospects" - Moscow (2014).

The problem of invasive species strongly concerns also the central part of Ukraine. The aim of the study was to investigate the distribution of 10 selected species of foreign origin in the Romensko-Poltawsky Geobotani- cal District. The study included 8 invasive species (Acer negundo, Amaranthus retroflexus, Ambrosia artemisiifolia, Conyza canadensis, Iva xanthiifolia, Portulaca oleracea, Setaria glauca, Solidago canadensis) and 2 potentially invasive species (Asclepias syriaca and Parthenocissus quinquefolia).

\section{Material and methods}

The study area is the Romensko-Poltavsky Geobotanical District (Fig. 1). It is located in the central part of Ukraine and comprises the Poltava region (without the southern part), south-eastern and western parts of Kharkiv region and southern part of Sumy region. This is an interesting area for research, because it has a long history of social and economic development, which led to synanthropisation of almost all natural ecosystems.

At first, we performed a study of alien flora and invasions in the studied region (Dvirna 2014). The data were obtained during the field research conducted in 2010-2014. The grid method of plant mapping was used (Budzhak \& Dvirna 2014). The maps show the species localities recorded from 1853 (by O. S. Rogovuch) to 2014 for the region. In these maps were prepared using the UTM coordinate system. The grid size was $5 \times 5$ $\mathrm{km}$, which is consistent with the grid adopted in Atlas of Florae Europaeae. Maps were developed using the MapInfo system. The adopted scale was 1:200,000. The territory of Romensko-Poltavsky Geobotanical 


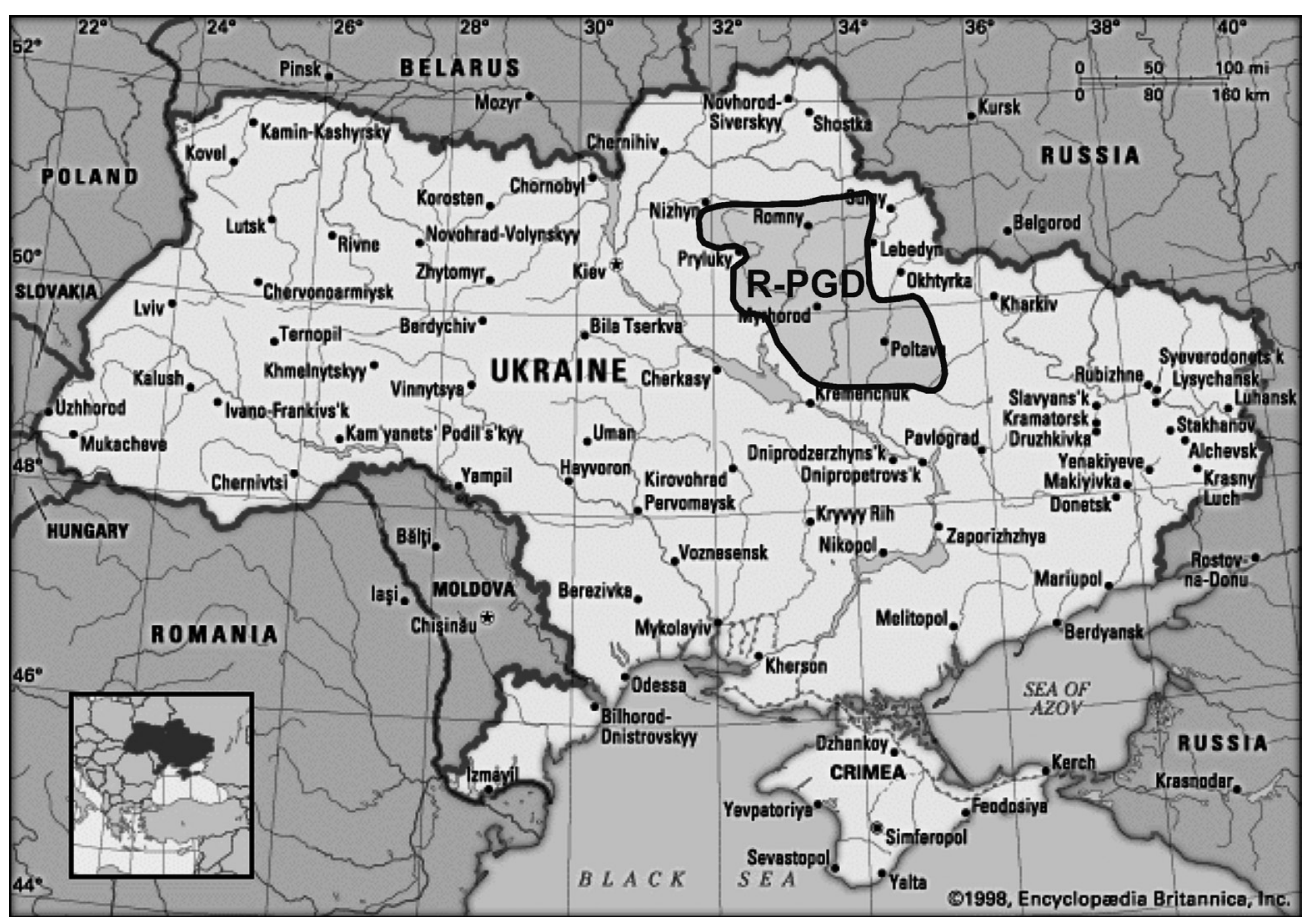

Fig. 1. The location of the Romensko-Poltavsky Geobotanical District (R-PGD) in Ukraine

District includes 18 squares $(50 \times 50 \mathrm{~km})$ of UTM grid. Each square is divided into 100 squares of $5 \times 5 \mathrm{~km}$. For mapping of invasive and potentially invasive species, the separate layers of maps were prepared and stored in an electronic database. The database includes information on a given species occurrence and the number of its localities in a square.

The classification of invasive species follows Richardson et al. (2000). The analysis of the region's alien flora was conducted according to generally accepted methods: taxonomical and florogenetic (Tolmachev 1974, 1986), geographical-historical (Kornaś 1968), biomorphological (life forms) (Raunkiaer 1934; Serebryakov 1962), geographical analysis of hierarchical system of geoelements (Kleopov 1990) and coenotic (Belgard 1971). Characteristics of biotopes were used according to Didukh et al. (2011) and the terms describing the scale of hemoroby - after Jalas (1955) and Blume and Sukopp (1976).

\section{Results and discussion}

The alien flora of the study region includes 342 species of vascular plants belonging to 207 genera and 61 families (Dvirna 2014). In general, the alien flora of the Romensko-Poltavsky Geobotanical District is heterogeneous, its structure has both the features of Ancient Mediterranean flora and arid and anthropogenically transformed areas. The main features of this region's flora are similar to features characteristic for the alien flora of Ukraine.
In the species composition of the studied flora, 8 invasive and 2 potentially invasive species were found, which represents about $3 \%$ of the total number of alien species in this area.

Acer negundo L.: kenophyte of the North American origin (Vinogradova et al. 2010), agrio-epoecophyte, ergasio-xenophyte (Dvirna 2014). The data on the beginning of its cultivation and running wild are not available, we can only assume that this happened, approximately, in the 40s of the last century (Kiev, near the Botanical Gardens nursery, A. I. Barbarich, 1944, KW). The species grows mainly on poor compacted soils with weak aeration. Habitat is generally well lit, but some species can withstand shade.

We found out that $A$. negundo has a uniform pattern of distribution in the studied territory. It occurs mainly in anthropogenically disturbed areas - along railways and highways, in the areas with unused buildings or construction sites. In most cases, this species is polyhemerobic, but sometimes $\alpha$-euhemerobic. Partially, it naturalized in forest and shrub communities, where it can be subdominant (Ojcius \& Kostolovych 2014). The map shows the range of the species spread (Fig. 2). It predominates in the south-western part of the region and is confined to the disturbed habitats and areas prone to potential invasion (vicinity of research stations and along railway tracks and highways). In general, the species occupies 2 or 3 types of habitats, where it grows singly.

The centres of its distribution are cultivation places, from which it spreads by self-seeding. In most cases, $A$. 


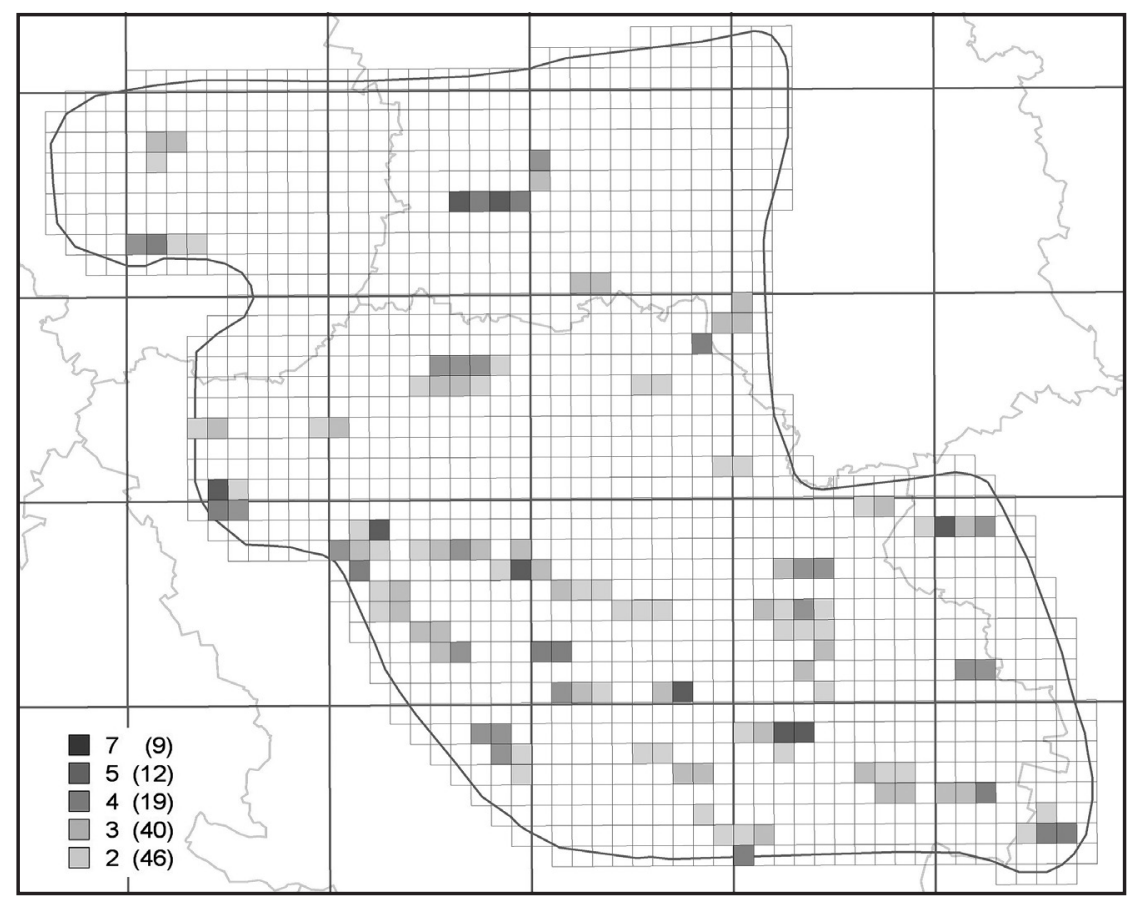

Fig. 2. The distribution of Acer negundo in the Romensko-Poltavsky Geobotanical District

Explanations: 2-7 - the number of biotops per square; in brackets - the number of squares with a given number of biotops

negundo occurs singly, forming thickets only along the roadsides. Acer negundo occurs in the different types of habitats, such as G and I groups of biotopes (Table 1 ), where it grows singly and doesn't form thickets.

Amaranthus retroflexus L.: kenophyte of the North American origin (Costea et al. 2004), epoecophyte, xenophyte (Dvirna 2014). The first mention about the species occurrence in the studied area was recorded by S. Ilichevs'kyj in 1927 and refers to the Vorskla river within the city of Poltava (Ilichevs'kyj 1928). A. retroflexus grows in different soil types, such as fertile black soil, and an impoverished mixed type (black soil with gray or ashed soils). Habitat is open. The species has a uniform pattern of distribution in the region. It has

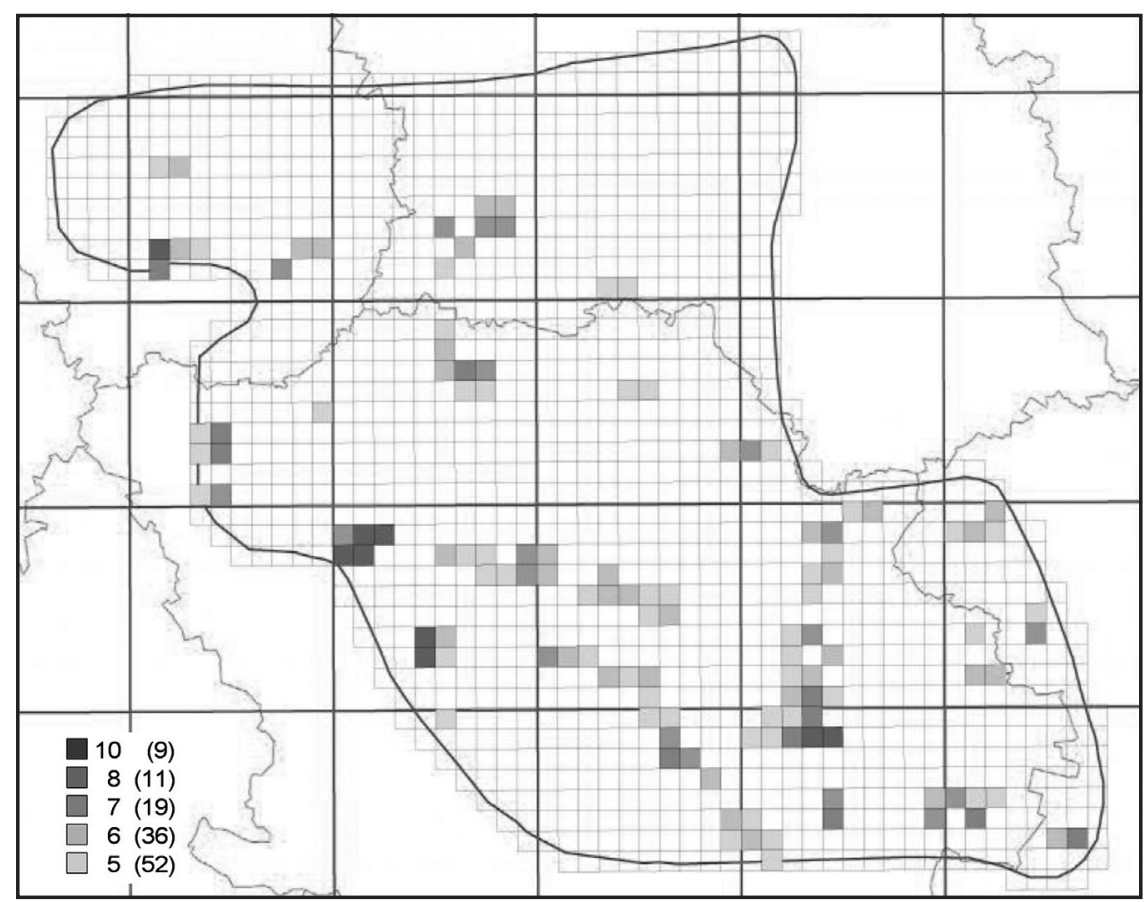

Fig. 3. The distribution of Amaranthus retroflexus L. in the Romensko-Poltavsky Geobotanical District

Explanations: 5-10 - the number of biotops per square; in brackets - the number of squares with a given number of biotops 
been actively spread by humans in anthropogenically transformed areas - along the roadsides and railway tracks, on trash dumps in the vicinity of closed factories, in unused farms and, most often, in agrocoenoses (fields and orchards). It is a typical $\beta$-euhemerobic species. It occurs singly and can occupy small areas - mainly in agrocoenoses (Fig. 3). A. retroflexus is mostly concentrated in the south and east parts of the studied area and occurs in the I group of biotopes (Table 1).
Ambrosia artemisiifolia L.: kenophyte of North American origin (Payne 1966), epoecophyte, ergasioxenophyte (Dvirna 2014). No reliable data about the first appearance of $A$. artemisiifolia in Ukraine are known. Possibly, this happened in the beginning of the last century, because the first relevant information refers to the years 1914-1918 and concerns the Kudashivka station, Dnipropertrovsk region, where the species was cultivated (Marjushkina 1986).

Table 1. The occurrence of invasive species in different of biotopes

\begin{tabular}{|c|c|c|c|c|c|c|c|c|c|c|}
\hline Biotops/Number of species & 1 & 2 & 3 & 4 & 5 & 6 & 7 & 8 & 9 & 10 \\
\hline $\begin{array}{l}\text { E Mesophytic and xerophytic grasslands with dominance of } \\
\text { hemicryptophytes (meadows, steppes, heaths) }\end{array}$ & $\cdot$ & - & . & . & + & . & . & + & . & . \\
\hline $\begin{array}{l}\text { E3 Heath-like biotopes on silica sands: Nardetalia, Koelerio- } \\
\text { Corynephoretea, Festucetea vaginatae }\end{array}$ & . & . & . & . & + & . & . & + & . & . \\
\hline E3.1 Xeromesophytic grasslands (Nardetalia) & . & . & . & . & + & . & . & . & . & . \\
\hline $\begin{array}{l}\text { E3.13 Mixed-species psammophytic grasslands (Thymus serpyllum, } \\
\text { Helichrysun arenarium, Hieracium pilosella, Oenothera biennis s.l., } \\
\text { Artemisia campestris s.1.) }\end{array}$ & . & . & . & . & + & . & . & . & . & . \\
\hline E3.2 Xerophytic azonal grasslands on sandy terraces & . & . & . & . & . & . & . & + & . & . \\
\hline $\begin{array}{l}\text { E3.22 Psammophytic azonal grasslands dominated by non-tussock } \\
\text { grasses (Calamagrostis epigeios, Secale sylvestris) }\end{array}$ & . & $\cdot$ & $\cdot$ & $\cdot$ & $\cdot$ & $\cdot$ & $\cdot$ & + & $\cdot$ & . \\
\hline G Biotopes dominated by phanerophytes (forests, scrubs) & + & . & . & . & . & . & . & . & . & + \\
\hline G1 Broadleaved deciduous forests & + & . & . & . & . & . & . & . & . & + \\
\hline G1.12 Forests dominanted by Betula, Populus tremula & . & . & . & . & . & . & . & . & . & + \\
\hline G1.123 Birch fresh and dry forests (Betulo-Quercetum roboris) & . & . & . & . & . & . & . & . & . & + \\
\hline G1.124 Aspen forests (Populus tremula) & . & . & . & . & . & . & . & . & . & + \\
\hline $\begin{array}{l}\text { G1.23 Broadleaved forests and scrubs with dominance of other species } \\
\text { (Fraxinus, Tilia, Carpinus, Acer) }\end{array}$ & + & . & . & . & . & . & . & . & . & . \\
\hline G1.232 Linden-sycamore forests (Tilio-Aceretum pseudoplatani) & + & . & . & . & . & . & . & . & . & . \\
\hline $\begin{array}{l}\text { G1.2 Broadleaved forests and scrubs (Querco-Fagetea, Quercetea } \\
\text { robori-petraea) }\end{array}$ & . & $\cdot$ & . & $\cdot$ & . & . & . & . & . & + \\
\hline G1.21 Oak forests & . & . & . & . & . & . & . & . & . & + \\
\hline G1.216 Maple-linden-oak forests of Left-Bank Ukraine & . & . & . & . & . & . & . & . & . & + \\
\hline G1.3 Scrubs (Rhamno-Prunetea) & + & . & . & . & . & . & . & . & . & + \\
\hline $\begin{array}{l}\text { G1.32 Mesothermophilous maple scrubs (Lamio purpureae-Acerion } \\
\text { tatarici: Acer tataricum) }\end{array}$ & + & . & . & . & . & . & . & . & . & . \\
\hline I Cultivated agricultural biotopes & + & + & + & + & + & + & + & + & + & + \\
\hline I1 Agricultural biotopes with intensive cultivation & . & + & + & + & + & + & + & + & + & . \\
\hline I1.1 Agricultural biotopes with annual cultivation (segetal type) & . & + & + & + & + & + & + & + & + & . \\
\hline I1.11 Agrobiotopes of cereal crops & . & + & + & + & + & + & + & + & + & . \\
\hline I1.12 Agrobiotopes of non-cereal crops & . & + & + & + & + & + & + & + & + & . \\
\hline I2 Ruderal grass biotopes & + & + & + & + & + & + & + & + & + & . \\
\hline $\begin{array}{l}\text { I2.1 Biotopes of annual and biennial weeds of ruderal communities } \\
\text { and abandoned lands }\end{array}$ & $\cdot$ & + & + & + & + & + & + & + & + & . \\
\hline I2.2 Ruderal biotopes of perennial plants & + & + & + & + & + & + & + & + & + & . \\
\hline I3 Biotopes of forest clearings & + & & & + & & + & + & + & + & + \\
\hline I4 Artificial (cultivated) biotopes with trees and bushes & + & + & + & + & + & + & + & + & + & + \\
\hline $\begin{array}{l}\text { I4.1 Tree and bush self-regenerating plantations } \\
\text { I4.11 Wooded agrobiotopes }\end{array}$ & + & . & . & . & . & . & . & . & . & + \\
\hline $\begin{array}{l}\text { I4.111 Biotopes dominated by deciduous trees (Chelidonio-Robinion: } \\
\text { Robinia pseudoacacia, Acer negundo) }\end{array}$ & + & . & . & . & . & . & . & . & . & . \\
\hline I4.2 Ornamental and fruit plantations (gardens, parks) & $\cdot$ & + & + & + & + & + & + & + & + & + \\
\hline I5 Ornamental artificial grasslands & . & + & + & + & + & + & + & + & + & . \\
\hline
\end{tabular}

Explanations: 1 -Acer negundo, 2 -Amaranthus retroflexus, 3 - Ambrosia artemisiifolia, 4 - Asclepias syriaca, 5 - Conyza canadensis, 6 - Iva xanthifolia, 7 - Portulaca oleracea, 8 - Setaria glauca, 9 - Solidago canadensis, 10 - Parthenocissus quinquefolia 


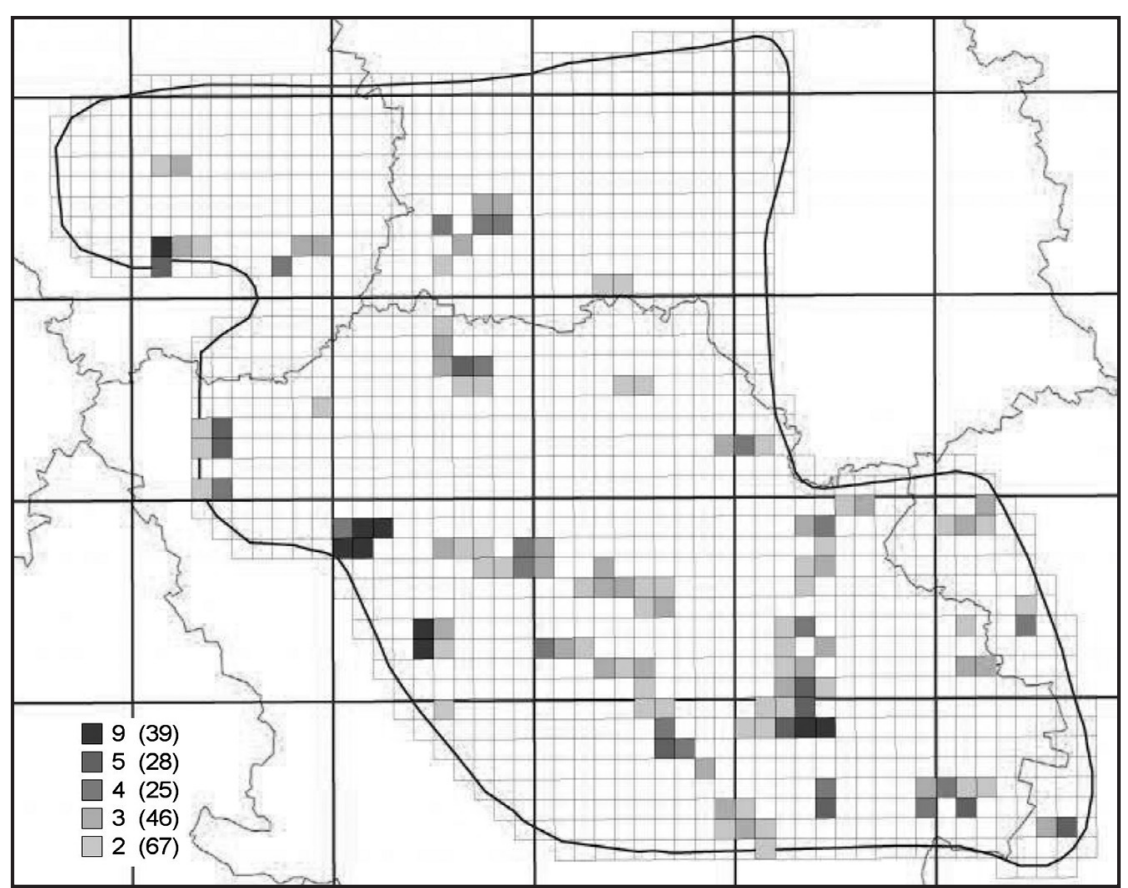

Fig. 4. The distribution of Ambrosia artemisiifolia L. in the Romensko-Poltavsky Geobotanical District Explanations: 2-9 - the number of biotops per square; in brackets - the number of squares with a given number of biotops

A. artemisiifolia occurs on different types of soil (fertile and poor). Compacted soil restricts the growth of plants, while aeration improves rooting and stimulates rapid development (Phisjunov et al. 1970; Marjushkina 1986). The species occupies well-lighted habitats, mostly polyhemerobic, but also $\alpha$-euhemerobic. It grows in fields, gardens, orchards, pasturages and along roadsides and streets in settlements; invades and sometimes displaces crop plants in agrocoenoses or plantations. Its distribution in the studied region is typical for Ukraine in general. The species has a uniform pattern of distribution in the studied district (Fig. 4). It is listed on the quarantine list. In 2003, A artemisiifolia covered more than 2327,82 hectares in total. It should

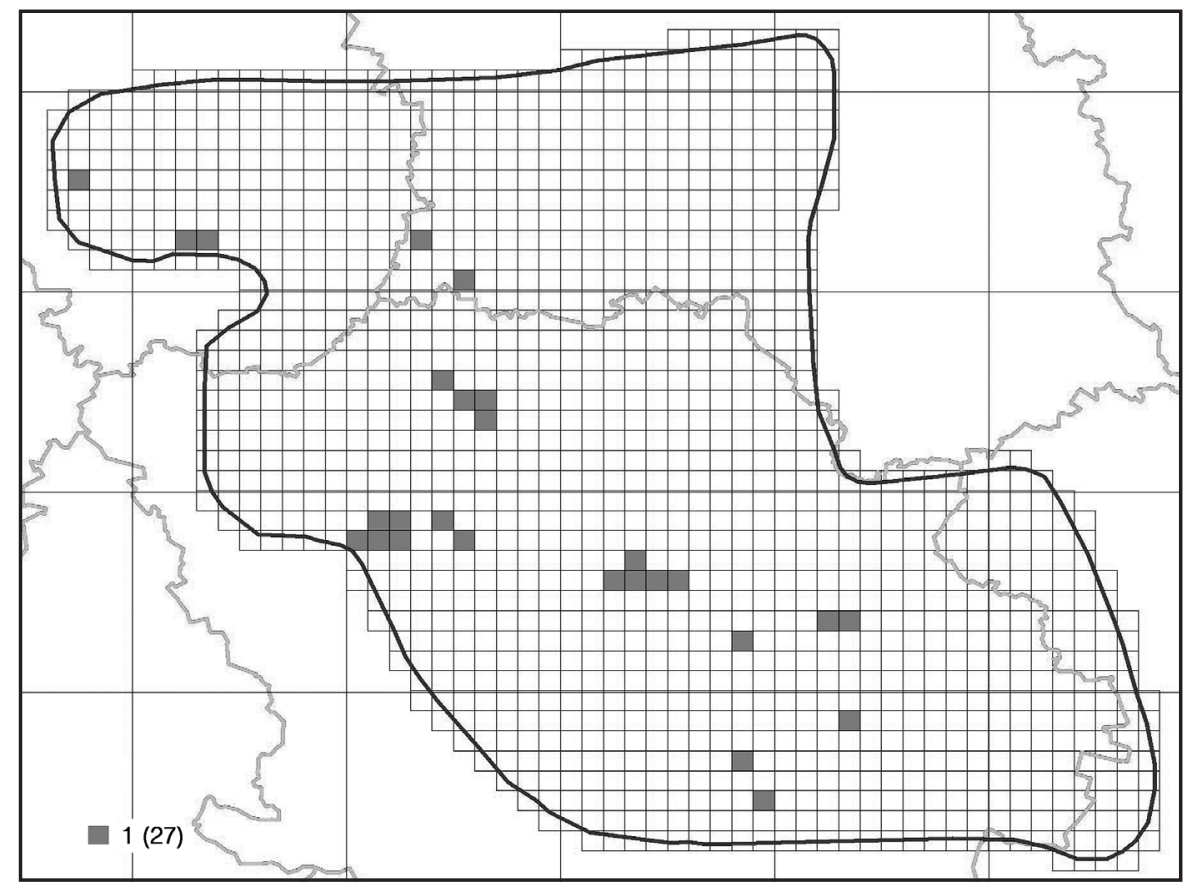

Fig. 5. The distribution of Asclepias syriaca L. in the Romensko-Poltavsky Geobotanical District

Explanations: 1 - the number of biotops per square; in brackets - the number of squares with a given number of biotops 


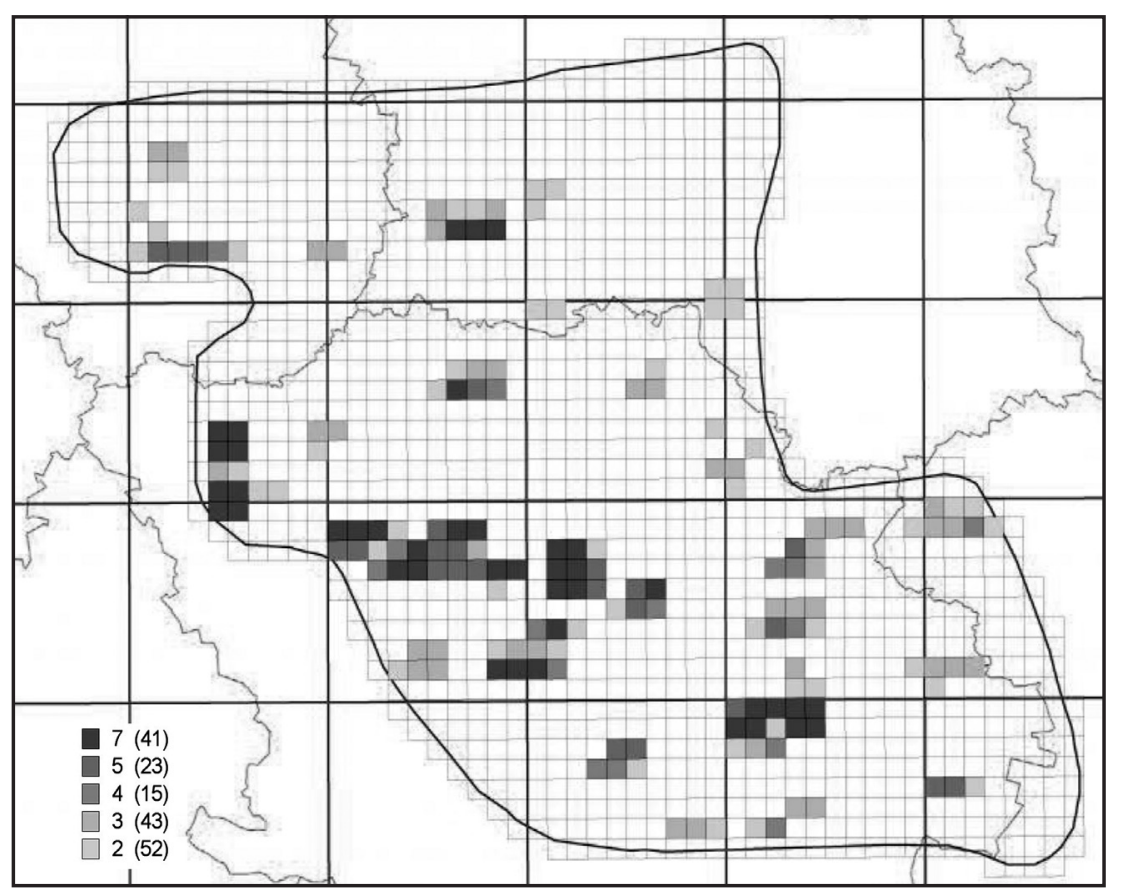

Fig. 6. The distribution of Conyza canadensis (L.) Cronq. in the Romensko-Poltavsky Geobotanical District Explanations: 2-7 - the number of biotops per square; in brackets - the number of squares with a given number of biotops

be noted that, considering its biomorphological and environmental adaptation possibilities, it has a highly invasive potential, although it is not a transformer species. Perhaps, this phenomenon can be explained by the fact that its spread is actively controlled to prevent a radical change in natural and semi natural communities. A. artemisiifolia has an even pattern of distribution and mostly occupies such areas as cultivated fields, vegetable gardens and roadsides, where it forms small groups or grows singly. It participates in I group of biotopes (Table 1).

Asclepias syriaca L.: kenophyte of the North American origin (Protopopova 1991), colonophyte, ergasiophyte (Dvirna 2014). A. syriaca was noted for the first time in 1869 in the weedy locations and large gardens (Rogovych 1869), and reported as feral in 1886 (Schmalhausen 1886). It grows in different soils and tolerates shading, although shade may decrease its growth. The species has a dispersed pattern of distribution (Fig. 5). A. syriaca mainly grows along roadsides, in ruderal localities - near places of cultivation, sometimes, it occurs in meadow phytocoenoses, where it can occupy large areas. It is a typical $\beta$-euhemerobic species. We suppose that in future, $A$. syriaca will invade semi natural vegetation and will spread in the southern and western parts of the country.

The distribution map of $A$. syriaca shows that the species occurs mainly in the central part of the studied region. The map presents those squares that comprise one locality with an area of more than 5 hectares (Fig. 5). In one square, $A$. syriaca occupies only one type of phytocoenoses. The species occurs in I group of biotopes, where it forms clumps (Table 1).

Conyza canadensis (L.) Cronq.: kenophyte of the North American origin (Frankton \& Mulligan 1987), epoecophyte, xenophyte (Dvirna 2014). C. canadensis has been noted in the studied area since 1869 -in stubble fields, sterile places and thickets (Rogovych 1869). It occurs in natural and secondary habitats on coarse soils and prefers rocky, sandy or rich loamy soils (Weaver 2001; Vinogradova et al. 2010), which are poorly managed, as well as well-lit habitat. It occurs all over the region and has a uniform pattern of distribution (Fig. 6). Conyza canadensis is a pioneer plant in the disturbed areas (Vinogradova et al. 2010). It grows mainly in the disturbed, anthropogenic communities (railway grounds, embankments, roadsides, farmland, non-functioning building sites, landfills and dumps), and can also invade meadows and forest communities (Vinogradova et al. 2010). The species is euhemerobic or polyhemerobic.

The distribution map (Fig. 6) shows that C. canadensis is mainly distributed in the south and east parts of the region. From 2 to 7 different localities are included in one square. The species occurs, among others, in gardens, fields, dumps, flower beds and railway grounds., In such places, it grows mostly singly. The species participates in a few groups of biotopes, such as E and I. In the I group of biotopes, it grows mainly singly, but in the E group - it can participate in different plant communities (Table 1).

Iva xanthiifolia (Nutt.) Fresen: kenophyte of the North American origin (Jackson 1960), epoecophyte, 


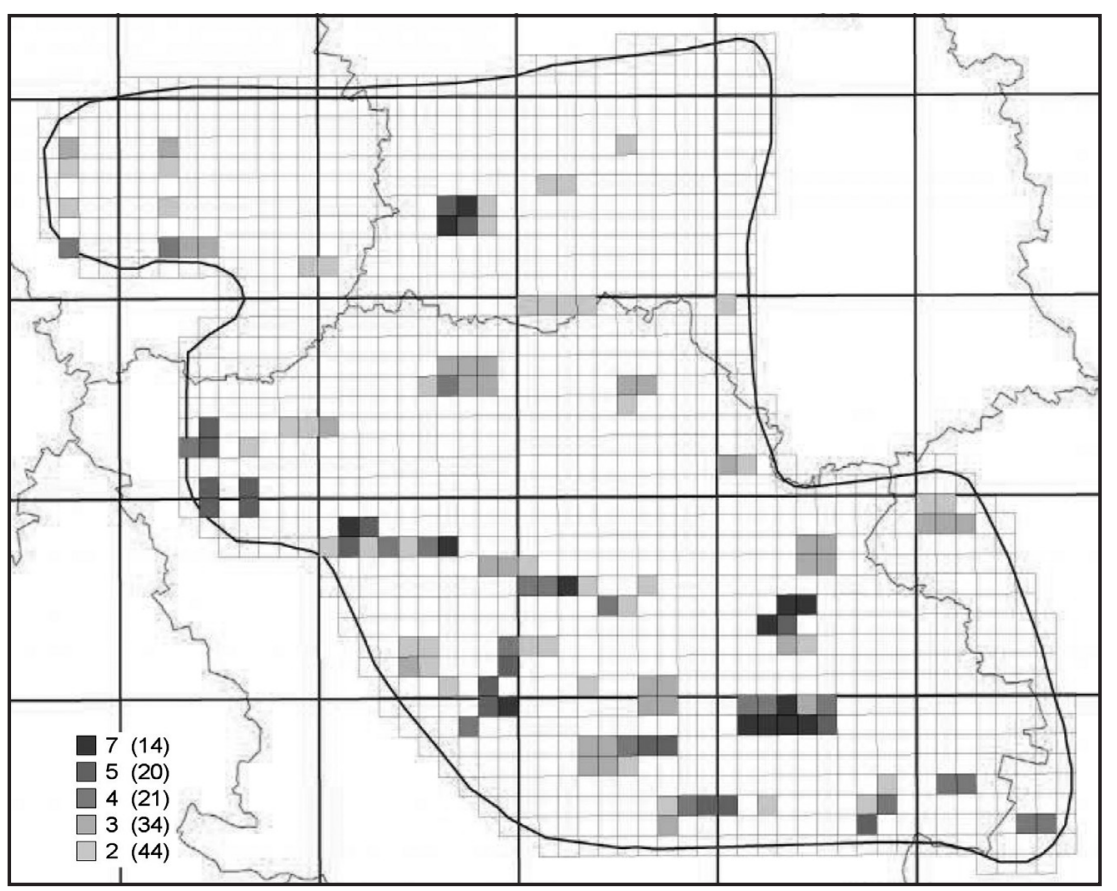

Fig. 7. The distribution of Iva xanthiifolia (Nutt.) Fresen in the Romensko-Poltavsky Geobotanical District Explanations: 2-7 - the number of biotops per square; in brackets - the number of squares with a given number of biotops

xenophyte (Dvirna 2014). The first mention on the occurrence of I. xanthiifolia is in the work by A. Rogovych (1869). This author reported that the species escaped from the Botanical garden of the University of St. Vladimir in 1842 and spread in many disturbed areas of Kiev and its outskirts. I. xanthiifolia grows successfully on any type of soil. In the studied re- gion, the species was found along the roadsides and railway tracks, in agrocoenoses (fields, orchards), on garbage dumps and in various man-made areas. It has an even distribution pattern (Fig. 7). The species is euhemerobic or polyhemerobic. It actively migrates to disturbed areas, especially man-made, and aggressively competes with weeds. In weed communities, it

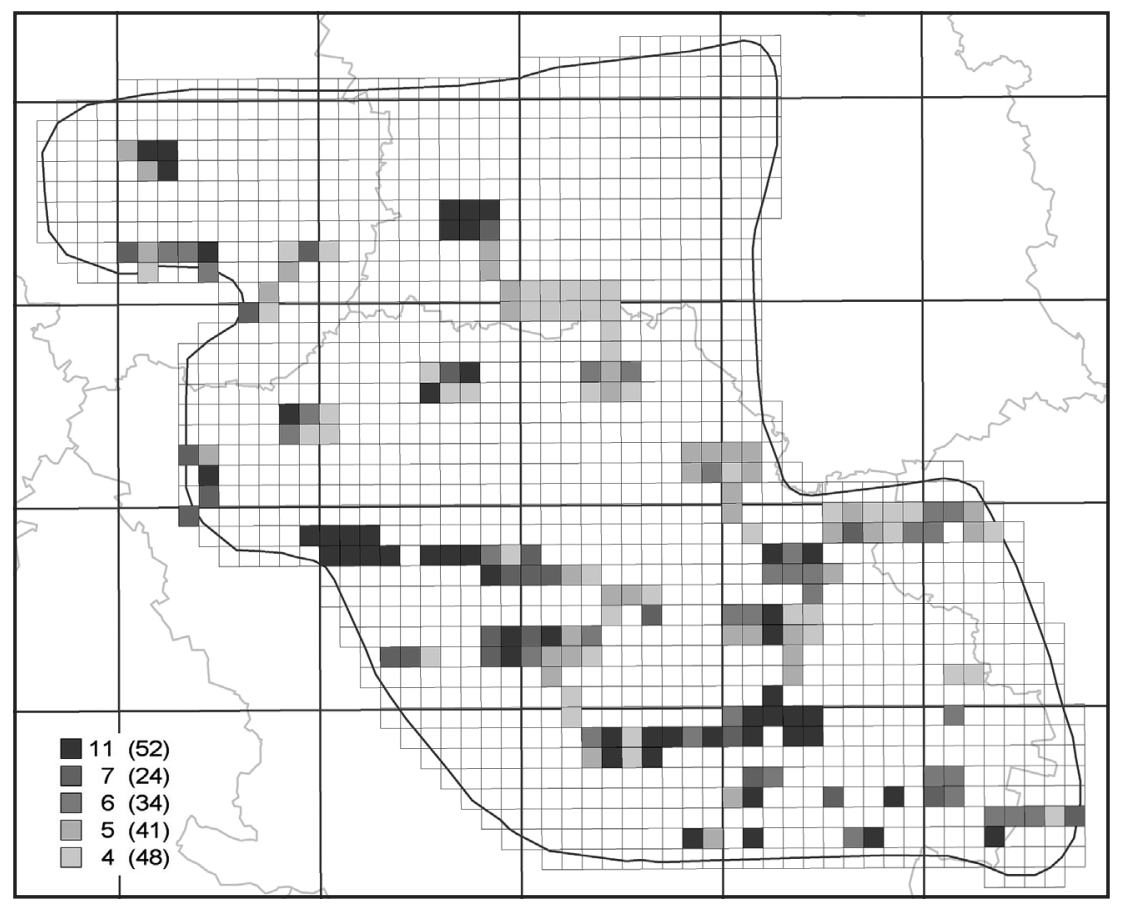

Fig. 8. The distribution of Portulaca oleracea L. in the Romensko-Poltavsky Geobotanical District Explanations: 4-11 - the number of biotops per square; in brackets - the number of squares with a given number of biotops 


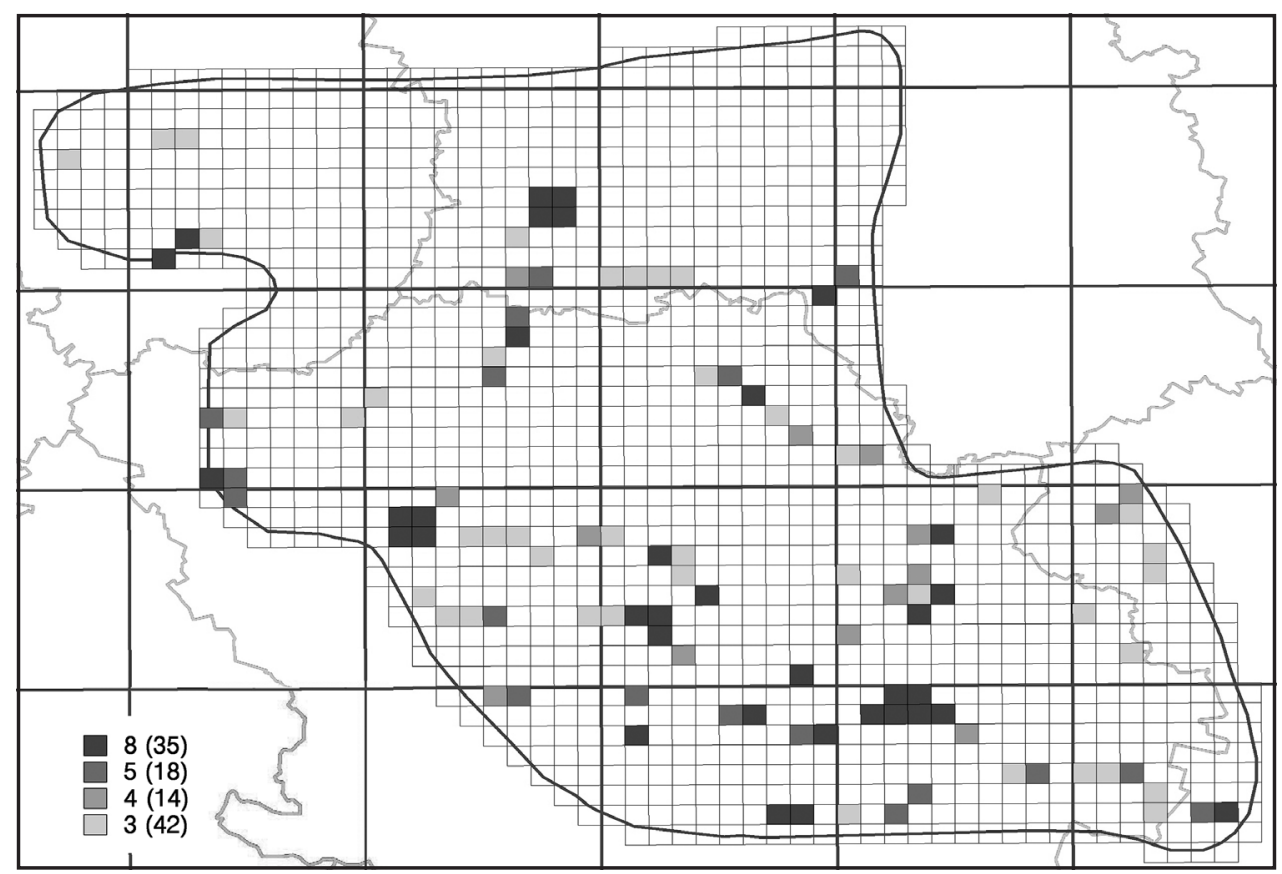

Fig. 9. The distribution of Setaria glauca (L.) P. Beauv. in the Romensko-Poltavsky Geobotanical District Explanations: 3-8 - the number of biotops per square; in brackets - the number of squares with a given number of biotops

quickly becomes a dominant species (Vinogradova et al. 2010).

I. xanthiifolia is mainly concentrated in the south and central parts of the studied region. Mostly, two or three localities are included in one square. These localities can be situated, among others, at the roadsides of rural roads, in vegetable gardens, fields and railway grounds. Iva xanthiifolia participates only in I type of biotope and mostly grows in groups, very seldom singly (Table 1).

Portulaca oleracea L.: archaeophyte of the IranoTuranian origin (Protopopova 1991), epoecophyte, xenophyte (Dvirna 2014). The first observations of $P$. oleracea in the studied region were made in 1886 by Schmalhausen, who noted that this species occurred "on sandy soil, in the fields. Poltava. Lybnu". In the studied region, the species has a uniform pattern of distribution (Fig. 8). It grows mainly in the different types of agrocoenoses such as fields, orchards, gardens and flower beds. Sometimes, it is also found along railway tracks and roadsides. We noted that the species is able to occupy large areas, where it forms a continuous cover, but does not displace crops. Portulaca oleracea grows in fertile soil and in open, well-lit habitats. It is mainly a $\beta$-euhemerobic species.

The species is mainly concentrated in the central and southern parts of the region. In a few squares of the map, it occupies such types of habitats, as: fields and vegetable gardens, gardens and flower beds, railway grounds or rural roadsides. P. oleracea participates only in the I group of biotopes and mostly covers large areas (Table 1).
Setaria glauca (L.) P. Beauv.: archaeophyte of the Indo-Malaysian origin (Protopopova 1991), epoecophyte, xenophyte (Dvirna 2014). S. glauca was for the first time reported in 1869 from the Kiev's province (Rogovych 1869). The species is widespread over the whole studied region and can grow on different soils (black, gray, ashed and mixed), prefers well-lit areas, but tolerates also shading. In the studied region, it has a uniform pattern of distribution (Fig. 9). S. glauca occurs in anthropogenically transformed areas - dump, garbage, roads and railway grounds, invades all types of agrocoenoses (fields, orchards, gardens and flower gardens) and enters semi natural communities - forest edges, grasslands and coastal vegetation. It is an euhemerobic species.

The distribution map shows that $S$. glauca is distributed all over the studied region, except the north-east part that is under reserve protection. The species participates in two groups of biotopes - E and I. In both types, it grows singly or in communities as an accompanying or subdominante species (Table 1).

Solidago canadensis L.: kenophyte of the North American origin (Weber 1998; Harnett \& Bazzaz 1983), epoecophyte, ergasiophyte (Dvirna 2014). The first spontaneous populations of $S$. canadensis were recorded by Schmalhausen in 1886 . Due to the high adaptive abilities, it can grow on soils with different mechanical composition (from light sand to heavy clay) (Vinogradova et al. 2010) and tolerates shade. In the study area, the species has a uniform distribution pattern (Fig. 10). It occurs in the various types of anthropogeni- 


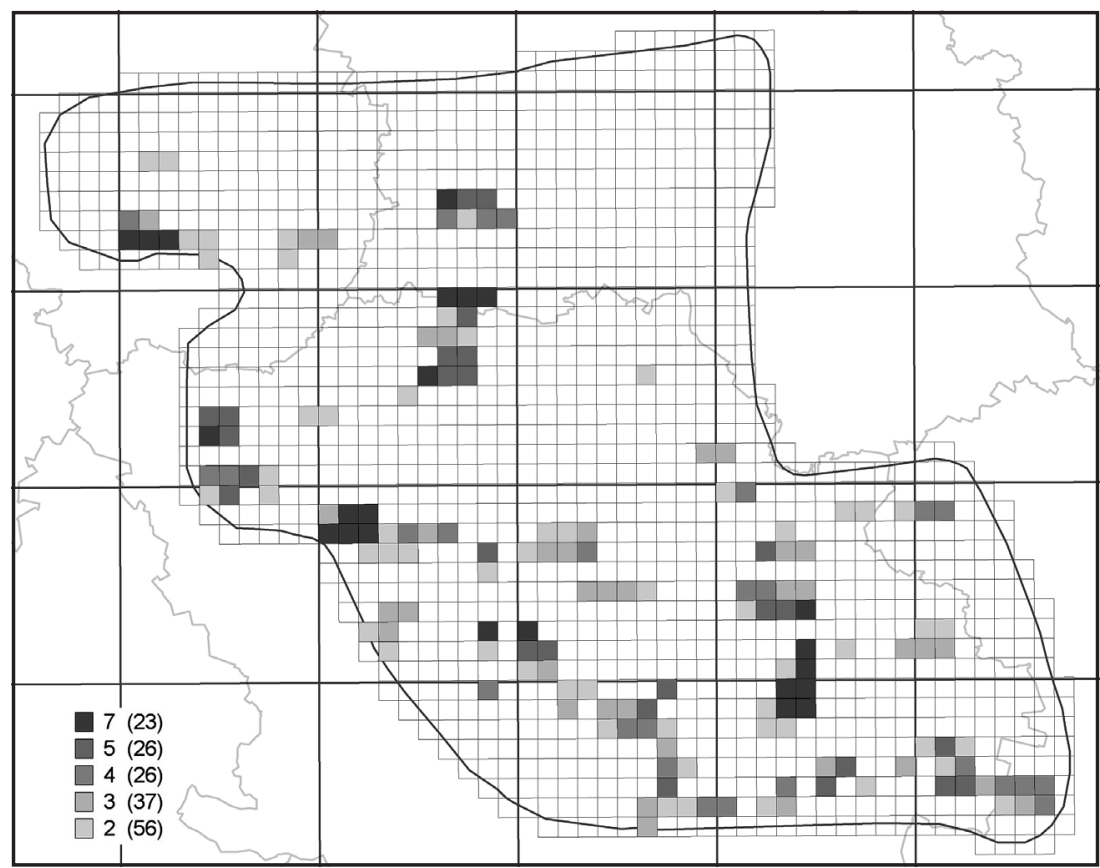

Fig. 10. The distribution of Solidago canadensis L. in the Romensko-Poltavsky Geobotanical District

Explanations: 2-7 - the number of biotops per square; in brackets - the number of squares with a given number of biotops

cally transformed habitats, such as: railway grounds, roadsides, cemeteries, dumps and agrocoenoses. It also enters semi natural meadows and forests. S. canadensis can form communities with some other species, in which it is dominant (Vinogradova et al. 2010). It is a polyhemerobic species.

This species is mainly distributed in the central and eastern parts of the region. One square includes dif- ferent localities - a few squares contains 7 localities, such as: roadside, railway area, semi natural meadow, garden vicinity, field and dump. S. canadensis may grow in small groups or singly and participates only in the I group of biotopes (Table 1).

Parthenocissus quinquefolia (L.) Planch: kenophyte of the North American origin (Pringle 2010), epoecophyte, ergasiophyte (Dvirna 2014). No data on early

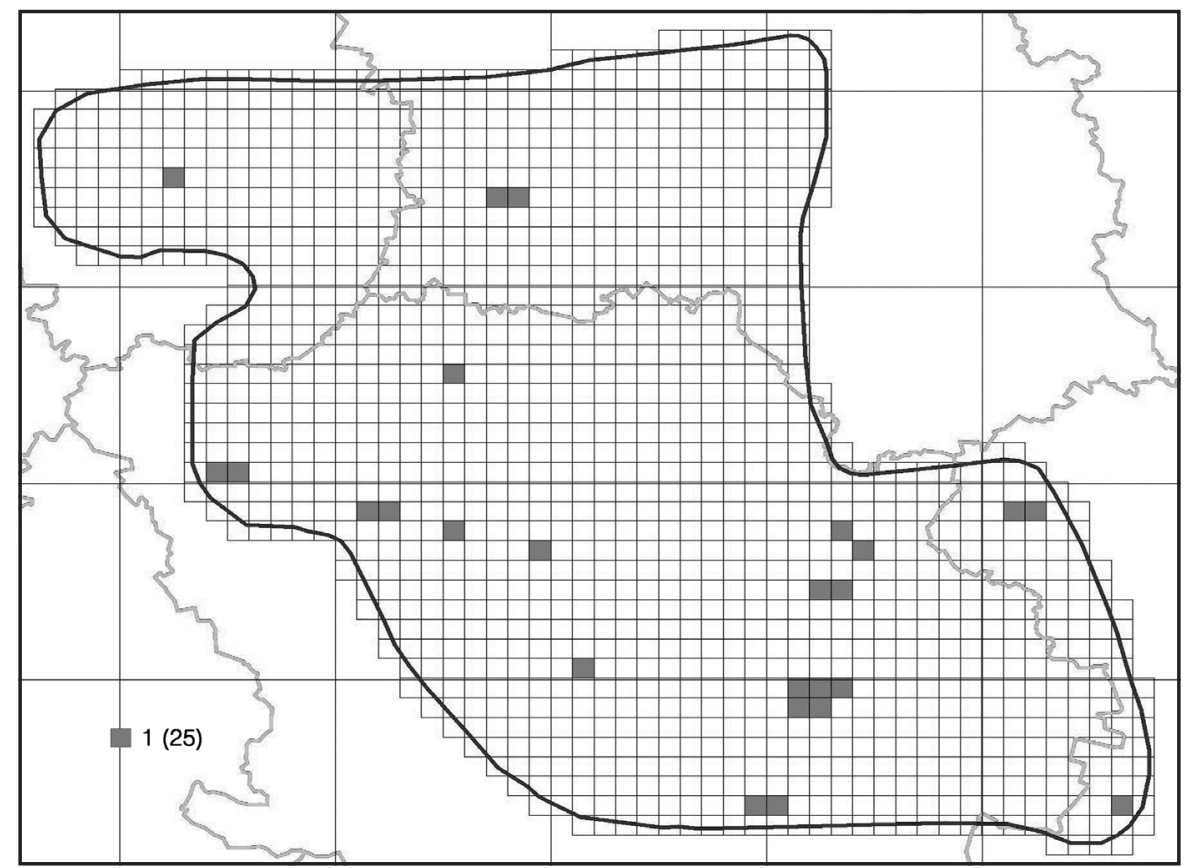

Fig. 11. The distribution of Parthenocissus quinquefolia (L.) Planch in the Romensko-Poltavsky Geobotanical District Explanations: 1 - the number of biotops per square; in brackets - the number of squares with a given number of biotops 
cultivation of $P$. quinquefolia and its running wild in the studied territory are available. The species prefers soils with different mechanical structure and tolerates shading. It is distributed mainly along railway tracks, on building walls, in forest or other artificial plantations, where it can quickly forms a continuous cover. Taking into account its biomorphological and eco-coenotic features (undemanding to soil and light conditions, fast spread), it is a potentially invasive species. P. quinquefolia is $\alpha$-euhemerobic or polyhemerobic. We assume that over time it will get a new status. The map of distribution shows that this species is mainly distributed from west to east with increasing tendency (Fig. 11). It covers small area and participates in the $\mathrm{G}$ and I groups of biotopes (Table 1) .

\section{Conclusion}

An analysis of the present state of distribution of invasive species in the Romensko-Poltavsky Geobotanical District shows some general tendency - these species are most intensively distributed in the north and northwest parts of the district, especially along the Kyiv-Kharkiv highway and railway track, around large railway stations (Poltava, Grebinka, Romnu, Krasnograd), in the vicinity of Research Station of Medicinal Plants and in used agrocoenoses. In general, an optimum habitat type for invasive plant species is a ruderal-segetal type.

Invasive plant species of the Romensko-Poltavsky Geobotanical District are species with a wide ecological amplitude and high ecological plasticity, which allows them successfully naturalize and spread in heterogeneous environments. All these species are able to overcome the $\mathrm{E}$ (environmental - disturbed habitats) and $\mathrm{F}$ (environmental - natural habitats) barriers. It should be noted that a number of factors, such as: human influence on environment, gradual climate change, the spread of alien species and the number of invasive species are expected to increase in future.

Acknowledgement. The author would like to thank the anonymous reviewers and Dr hab. Zbigniew Celka for helpful comments and assistance in preparing the manuscript.

\section{References}

Baldacchino A. E. \& Pizzuto A. (eds.). 1996. Introduction of alien species of flora and fauna. Proceedings of Seminar held at Qawra, Malta, 5th March 1996, p. 77. Malta: EPD-Floriana.

Belgard A. L. 1971. Steppe Forestry. 336 pp. Forest industries, Moscow.

Blume H.-P. \& Sukopp H. 1976. Ökologische Bedeutung anthropogener Bodenveränderungen, Schriftenreihe für Vegetationskunde, 10: 75-89.

BudzhaK V. V. \& Dvirna T. S. 2014. Mapping of alien plant species of Romens-Poltava geobotanic area. Biol. syst. 6(1): 78-81.

Costea M., Weaver S. \& Tardif F. J. 2004. The biology of Canadian weeds. 130. Amaranthus retroflexus L., A. powellii S. Watson and $A$. hybridus L. Can. J. Plant Sci. 84: 631-668.

Davis M. 2003. Biotic Globalization: does competition from introduced species threaten biodiversity? BioScience 53: 481-489.

DVIRnA T. S. 2014. The alien fraction of the flora of the Romensko-Poltavsky Geobotanical District: an analysis and checklist. Phytodiver. of Eastern. Eur. 8(1): 4-19.

Didukh Y. P., Fitsailo T. V., Korotchenko I. A., IAKushEnko D. M. \& Pashrevych N. A. 2011. Biotopes of Forest and Forest-Steppe zones of Ukraine. 288 pp. Kiev.

Frankton C. \& Mulligan G. A. 1987. Weeds of Canada. 217 pp. Toronto, Ministry of Suppl. Serv, Canada. NC Press Ltd.
Harnett D. C. \& Bazzaz F. A. 1983. Phytosociological integration among interclonal ramets in Solidago canadensis. Ecology 64(4): 779-788.

ILICHEVs'KYJ S. O. 1928. Vegetation of Poltava vicinity. Notes of the Poltava's agricultural polytechnic college 11: 101-127.

JACKSON R. C. 1960. A revision of genus Iva. Univ. Kansas Sci. Bull. 41: 793-876.

JALAS J. 1955. Hemerobe und hemerochore Pflanzenarten. Ein terminologischer Reformversuch. Acta Societatia Pro Fauna et Flora Fennica 72: 1-15.

KLEOPOV Ju. D. 1990. Analysis of the flora broadleaf forests in the European part of the USSR. 350 pp. Naukova dymka Press, Kiev.

KornAś J. 1968. Geograficzno-historyczna klasyfikacja roślin synantropijnych. Mater. Zakł. Foitosoc. Stos. U.W. 25: 33-41.

Marjushinina V. Ya. 1986. Ambrosia artemisiifolia and the basics of biological control. 120 pp. Naukova dymka Press, Kiev.

Oscius L. \& Kostolovych M. 2014. Invasive plants the alien fraction flora of Volyn Polessey. Visnyk of the Lviv Univ. Series Geography. 45: 430-435.

PAYNE W. W. 1966. Notes on the ragweeds of South America with the description of two new species: Ambrosia pannosa and A. parvifolia (Compositae). Brittonia 18: 28-37.

Phisjunov A. V., Makodzeba I. A., Kozenko V. K. \& Shamkuy I. F. 1970. The quarantine weeds and their control. 150 pp. Promin Press, Dnepropetrovsk. 
Pringle J. S. 2010. Nomenclature of the thicket creeper, Parthenocissus inserta (Vitaceae). The Michigan botanist 49: 73-78.

Protopopova V. V. 1991. Synanthropic flora of Ukraine and ways of its development. 204 pp. Naukova dumka Press, Kiev.

Protopopova V. V., Mosyakin S. L. \& Shevera M. V. 2002. Plant invasions in Ukraine as a threat to biodiversity: The present situation and tasks for the future. $32 \mathrm{pp}$. M. G. Kholodny Institute of Botany, NAS of Ukraine, Kiev.

Protopopova V. V., Mosyakin S. L. \& Shevera M. V. 2003. Impact of alien plant species on the phytobiota of Ukraine. In: O. V. DuDKIN (ed.). Assessment and Mitigation of Threats to Biodiversity of Ukraine, pp. 129-155. Chimjest. Publ., Kiev.

RAUNKIAER C. 1934. The life form of plants and statistical plant geography. 632 pp. Claredon, Oxford.

Richardson D. N., Pyšek P., Rejmánek M., Barbour M. G., Panneta D. D. \& West C. J. 2000. Naturalization and invasion of alien plants: concepts and definitions. Diversity Distrib. 6: 93-107.

Rogovych A. S. 1869. Review of the seed and high spore plants that make up the flora of the provinces in Kiev educational district: Volyn, Podolia, Kiev, Chernigov and Poltava. 269 pp. Kiev.

SAX D. F. \& Gaines S. D. 2003. Species diversity: From global decreases to local increases. Trends Ecol Evol 18: 541-545.

Serebryakov I. G. 1962. The ecological morphology of plants. Life forms of angiosperms and gymnosperms. 379 pp. Vischaya shkola Press, Moscow.

Schmalhausen I. F. 1886. Flora oh the South-West Russian. 783 pp. Kiev.

Tolmachev A. I. 1974. Introduction in the geography of plants. 244 pp. Leningrad State University Press, Leningrad.

Tolmachev A. I. 1986. Methods of comparative floristics and problems of florogenesis. $196 \mathrm{pp}$. Nauka, Novosibirsk.

Vinogradova J. K., Mayorov S. R. \& Khorun L. V. 2010. Black book of flora of Middle Russia: alien plant species in the ecosystems of Middle Russia. 512 pp. GEOS, Moscow.

Weaver S. 2001. The biology of Canadian weeds. 115. Conyza canadensis. Canad. J. Plant. Sci. 81 (4): 867-875.

Weber E. 1998. The dynamics of plant invasions: A case study of three exotic goldenrod species (Solidago L.) in Europe. J. Biogeogr. 25: 147-154. 